\title{
Library funding and journal cancellations in South African university libraries
}

\author{
Ruth Hoskins 'and Christine Stilwell ${ }^{2}$ \\ Information Studies, School of Sociology and Social Studies, University of KwaZulu-Natal, Pietermaritzburg \\ hoskinsr@ukzn.ac.za; stilwell@ukzn.ac.za
}

Received: 10 July 2010

Accepted: 18 March 2011

\begin{abstract}
This article is based on part of a survey that investigated journal cancellations in university libraries in South Africa. A study population consisting of I7 university libraries in South Africa was surveyed by means of an online questionnaire to establish whether university libraries in South Africa were adequately funded and to gauge the impact of restrictive library budgets on journal cancellations. Interpretation of the results revealed South African university libraries, like most academic and research libraries world wide, have not been adequately funded and as a result have resorted to annual journal cancellations. Recommendations are made about enhancing library budgets to ensure continued access to library periodical collections.
\end{abstract}

Keywords: Journal cancellations; university libraries; South African university libraries; Funding university libraries

\section{Introduction and problem statement}

In the present scholarly communication system, libraries, which are the main facilitators in the scholarly communication system, are caught between the scholars and the publishers. Funding for the library, and the priority given to this within the overall institutional budgets, is a matter of great concern for librarians. As early as the 1960s the Parry Report (University Grants Committee on Libraries 1967) recommended that a library budget should be $6 \%$ of a university's total spending. Martell (2003) argues that during the 1970s academic libraries were faced with two major challenges. The first of these was deterioration in the levels of funding and the second was the never-ending spiral of annual increases for library periodicals and other materials. In the past, academic libraries had generally received budgets in the range of $6 \%$ or more of their institution's budget. However, as the university evolved and its needs changed, most specifically for computer-related equipment and software, libraries experienced a decline in their share of the overall university budget. By the late 1990s many academic libraries were receiving as little as $3 \%$ of their university's budget.

Furthermore, the loss in buying power caused by the annual cost-price increase for library periodicals ranging from 10 to $20 \%$ was, and is still, a major concern for most, if not all, academic libraries. Few academic libraries have been able to avoid the negative impact of these economic forces. Librarians, in an attempt to find solutions to these challenges have had to resort to annual journal cancellations:

Academic libraries are between a rock and a hard place. The decreasing access to scholarly materials is a very tough pill to swallow: It leads to an overall degradation of the library's collection, which in turn can lead to declines in the quality of research and teaching, drops in the reputation of the institution and its faculty, difficulties in recruiting faculty and students, and reduced chances of receiving program accreditation (Hoon 2003: 33).

This loss in buying power has subsequently resulted in a paradigm shift in how academic libraries operate since academic librarians could no longer maintain an adequate local print collection relative to their mission (collection paradigm). Instead they adopted a paradigm that reflected their fiscal realities, namely, the access paradigm (Martell 2003). Libraries now provide access to resources wherever they are located. Thus the role of the librarian has changed from that of 'keeper of information' to 'facilitator of access to information'. It is this problem of adequate funding and the consequence of journal cancellations that the study addresses, within the context of the South African university library. Based on the above-mentioned problem, the following research questions guided the conduct of the study:

- What percentage of the institutional budget was allocated to the university libraries?

- Do university libraries have separate budgets for print and electronic resources?

- What percentage of the university libraries' materials budget was allocated to periodical or serial subscriptions?

- What percentage of the university libraries' materials budget was allocated to monograph or book purchases?

- What were the reasons for university libraries cancelling journals?

I. Ruth Hoskins, Information Studies, School of Sociology and Social Studies, University of KwaZulu-Natal, Pietermaritzburg

2. Christine Stilwell, Information Studies, School of Sociology and Social Studies, University of KwaZulu-Natal, Pietermaritzburg

SA JnI Libs \& Info Sci 20II, 77(I) 
The study surveyed South African traditional and comprehensive university libraries. Universities of technology, or technikon, libraries were not included because research is not a major function for such institutions.

\section{Review of the literature}

The review of the literature examines the funding of university libraries in the United States (US), Africa and South Africa. Figure I provides a schematic diagram of funding for academic libraries in the US. Funding for libraries in Europe varies from country to country, but the basic structure is not much different from the US example (Gooden, Owen, Simon and Singlehurst 2002). The same could be said about academic libraries in South Africa. Academic libraries usually get their funding from the university they serve. The university is funded by a combination of state funds, endowments (funds built up from the contributions of alumni or corporate gifts) and tuition (student fees), and in some cases, local grants (particularly in the US). The exact split of funding depends on the type of university, with private universities getting almost no state funds. They are thus more reliant on endowments and tuition fees.

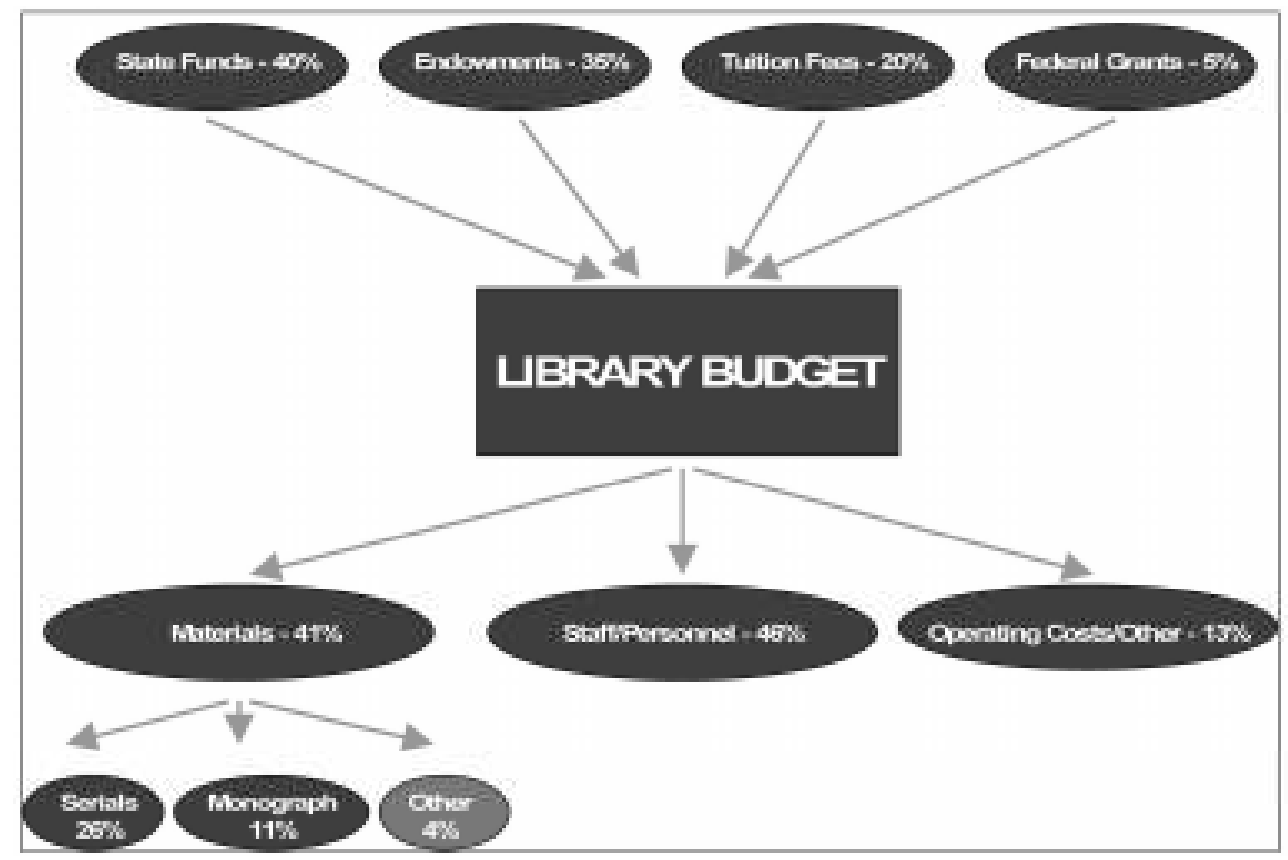

Gooden, Owen, Simon and Singlehurst (2002: 4)

Figure 1 Funding for US academic libraries

It is interesting to note that the serials or journals budget (26\%) for US academic libraries in the early 2000 s was more than double that of the monograph budget (II\%) allocation. However, the real enemy to acquiring scholarly knowledge is the rate of increases in price, regardless of a journal's initial price. According to Edwards and Shulenburger (2003) for a library budget to have maintained its journal collection unchanged from 1986 until 2000 would have required its subscriptions' budget to grow by $226 \%$. To keep pace with both price increases and the growth in the number of journals would have required a budget roughly five times the 1986 budget, that is, an increase of $428 \%$. During this period the average journal budget of Association of Research Libraries (ARL) members rose to 205\%. To increase its budget for journal subscriptions, the average library cutback severely on monograph purchases, by $17 \%$, as well as other services. Even with these cuts the average ARL library budget still fell short of what was needed, and therefore also cut the number of its journal subscriptions by $7 \%$.

\subsection{The consequences of bundling}

Edwards and Shulenburger (2003) maintain that an interesting development occurred in the late 1990s. Data on journal prices and acquisitions collected by the ARL showed that the average cost of scholarly journals to ARL libraries dropped by $7.3 \%$ between the years 2000 and 200 I. This drop in unit price was accompanied by an increase of $12 \%$ in the number of titles acquired. As a result, Edwards and Shulenburger (2003: 14) posed an important question regarding these circumstances, namely: "Does this remarkable change in direction indicate that the scholarly journals crisis ended in the year 2000?" 
For obvious reasons this did not indicate the end of the 'serials crisis' as many knowledgeable library authorities had another interpretation to explain the circumstances. In their view what happened was that several commercial publishers bundled their electronic journals into a single package referred to by librarians as the 'big deal'. So what had happened was that many librarians signed this deal because it did not increase the total price that they were paying for journals from a given publisher. According to Edwards and Shulenburger (2003) the increase in the number of journals acquired and subsequent drop in average price per unit were the result therefore of acquiring additional journals as part of these big package deals. Unfortunately, the journals added generally were not ones that the libraries placed a premium on acquiring and, in signing on to the package journals, the libraries lost the freedom to drop individual journal subscriptions for a period of time (generally three years) and thus obligated themselves to a fixed inflation rate for the packages (often $7 \%$ per year) for the duration.

\subsection{Expenditures in ARL libraries}

According to the Association of Research Libraries (2008) changes in the pricing models which publishers are using for electronic journals have had an observable effect on the data collected on serial prices and, consequently, on the serial unit cost ARL calculations. These changes do not necessarily reflect increased collecting of new content or reductions in the real costs of collection maintenance but are largely reporting the increased collecting of long-held subscriptions in multiple formats. In the late 1990s many e-journals were sold as free add-ons to existing print subscriptions. Initially, these subscriptions were counted as single subscriptions (one title received in both print and electronic form). This practice meant that the addition of electronic formats to earlier print subscriptions did not create an immediately observable rise in subscription counts. Beginning with the 2002 statistics, ARL responded to the increasingly common practice of pricing e-journals as either added charges to print subscriptions or as stand-alone subscriptions by allowing libraries to count a title received in two formats as two subscriptions. While not all members immediately adopted this practice, over the last several years the new counting practice, in combination with burgeoning collecting of e-versions of long-held print subscriptions, began to generate a noticeable increase in serial collection counts. Over time, as many libraries begin to reduce multi-format duplication by moving to e-only subscriptions for titles, the overall serial counts may decrease.

Similarly serial expenditures have increasingly included added payments made by ARL members to provide journals in electronic form in addition to print. Added expenditure, therefore, may not reflect the addition of new content to a collection. In fact, it is possible for a library's count of unique titles to shrink while both serials counts and expenditures increase if titles are cancelled to provide funds to add electronic versions of other titles collected. Figures 2 and 3 clearly indicate that journal expenditure in ARL libraries from 1986 to 2004 has increased by 273\%, with journal unit costs increasing by $188 \%$. The figures clearly show the impact on monograph purchases with a negative growth of $-9 \%$.

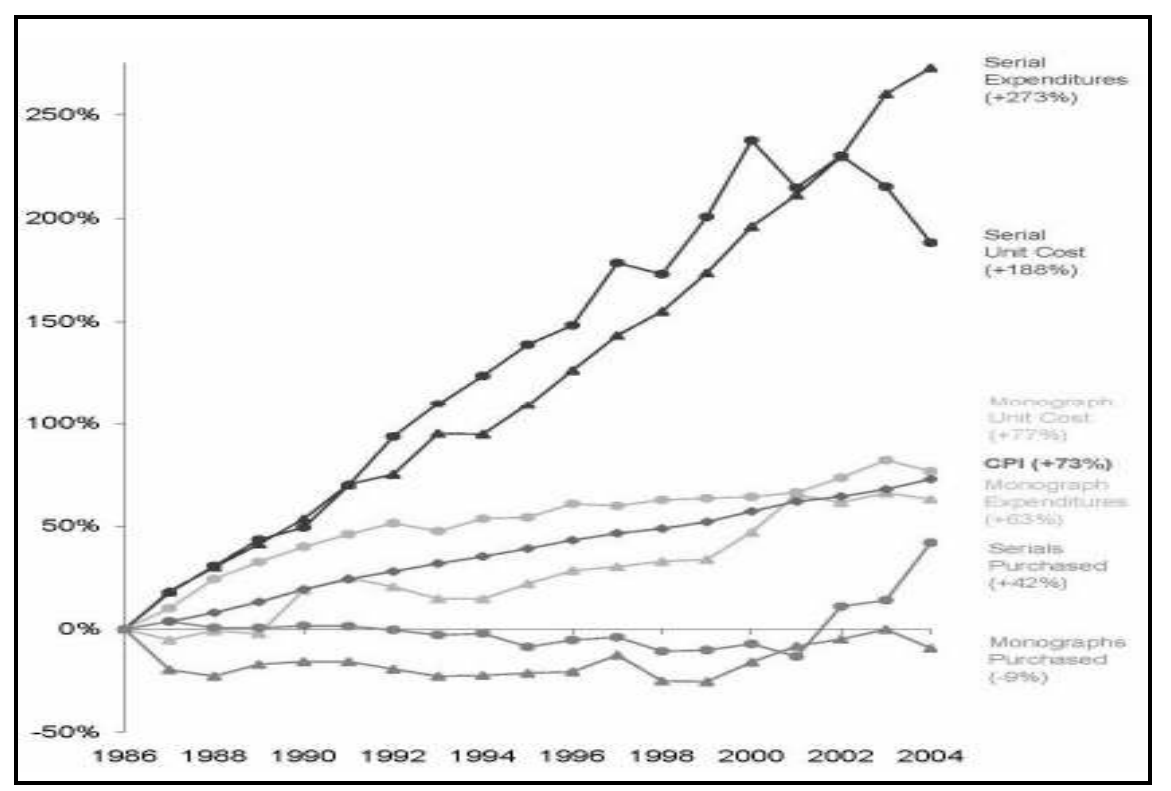

Association of Research Libraries (2008)

Figure 2 Monograph and serial costs in ARL libraries, 1986-2004 


\begin{tabular}{|c|c|c|c|c|c|c|}
\hline Year & $\begin{array}{r}\text { Serial } \\
\text { Unit Cost }\end{array}$ & $\begin{array}{r}\text { Serial } \\
\text { Expenditures }\end{array}$ & $\begin{array}{l}\text { Monograph } \\
\text { Unit Cost }\end{array}$ & $\begin{array}{l}\text { Monograph } \\
\text { Expenditures }\end{array}$ & $\begin{array}{r}\text { Serials } \\
\text { Purchased }\end{array}$ & $\begin{array}{l}\text { Monographs } \\
\text { Purchased }\end{array}$ \\
\hline (No. of Libraries) & (37) & $(102)$ & $(60)$ & (98) & (37) & $\overline{(60)}$ \\
\hline 1986 & $\$ 89.77$ & $\$ 1,496,775$ & $\$ 28.99$ & $51,118,931$ & 15,919 & 32,679 \\
\hline 1987 & $\$ 105.68$ & $\$ 1,769,960$ & $\$ 31.90$ & $\$ 1,060,754$ & 16,518 & 26,240 \\
\hline 1988 & $\$ 117.25$ & $\$ 1,947,559$ & $\$ 36.05$ & $\$ 1,109,845$ & 16,038 & 25,238 \\
\hline 1989 & $\$ 128.71$ & $\$ 2,113,976$ & $\$ 38.43$ & $\$ 1,093,858$ & 16,015 & 27,082 \\
\hline 1990 & $\$ 134.09$ & $\$ 2,296,910$ & $\$ 40.58$ & $\$ 1,329,950$ & 16,182 & 27.546 \\
\hline 1991 & $\$ 152.43$ & $\$ 2,548,687$ & $\$ 42.32$ & $\$ 1,396,566$ & 16,149 & 27,524 \\
\hline 1992 & $\$ 173.67$ & $\$ 2,620,832$ & $\$ 43.87$ & $\$ 1,348,786$ & 15,846 & 26,344 \\
\hline 1993 & $\$ 188.29$ & $\$ 2,918,569$ & $\$ 42.76$ & $\$ 1,284,116$ & 15,463 & 25,188 \\
\hline 1994 & $\$ 200.85$ & $\$ 2,912,495$ & $\$ 44.51$ & $\$ 1,282,569$ & 15,583 & 25,341 \\
\hline 1995 & $\$ 214.42$ & $\$ 3,131,033$ & $\$ 44.70$ & $\$ 1,365,046$ & 14.540 & 25,707 \\
\hline 1996 & $\$ 222.89$ & $\$ 3,389,118$ & $\$ 46.61$ & $\$ 1,437,028$ & 15,069 & 25,911 \\
\hline 1997 & $\$ 249.97$ & $\$ 3,642,541$ & $\$ 46.33$ & $\$ 1,457,789$ & 15,297 & 28,576 \\
\hline 1998 & $\$ 245.05$ & $\$ 3,816,497$ & $\$ 47.15$ & $\$ 1,486,436$ & 14,201 & 24,447 \\
\hline 1999 & $\$ 269.98$ & $\$ 4,095,934$ & $\$ 4740$ & $\$ 1,496,687$ & 14,303 & 24,355 \\
\hline 2000 & $\$ 303.19$ & $\$ 4,430,812$ & $\$ 4758$ & $\$ 1,645,248$ & 14,772 & 27,469 \\
\hline 2001 & $\$ 282.54$ & $\$ 4,660,349$ & $\$ 48.20$ & $\$ 1,848,622$ & 13,806 & 29.989 \\
\hline 2002 & $\$ 296.50$ & $\$ 4,939,225$ & $\$ 5026$ & $\$ 1,806,964$ & 17,673 & 31,079 \\
\hline 2003 & $\$ 283.08$ & $\$ 5,392,007$ & $\$ 52.75$ & $\$ 1,858,280$ & 18,142 & 32,649 \\
\hline 2004 & $\$ 258.73$ & $\$ 5,580,157$ & $\$ 51.19$ & $\$ 1,824,296$ & 22,595 & 29,633 \\
\hline $\begin{array}{l}\text { Average annual } \\
\text { percent change }\end{array}$ & $6.1 \%$ & $7.6 \%$ & $3.2 \%$ & $2.8 \%$ & $2.0 \%$ & $-0.5 \%$ \\
\hline
\end{tabular}

Association of Research Libraries (2008)

Figure 3 Monograph and serial expenditure in ARL libraries, 1986-2004

Median values for time-series trends

\subsection{Periodicals price survey}

The annual Library Journal, "Periodical price survey 2007: serial wars", "Periodicals price survey 2008: embracing openness" and "Reality bites: periodicals price survey 2009", conducted by Van Orsdel and Born (2007; 2008; 2009) provide some interesting statistical information. This survey examines the factors shaping the journal marketplace. According to Van Orsdel and Born (2007) academic libraries in the US saw an overall journal price increase of just under $8 \%$ for a second year in a row while in 2008 prices of subscription based journals increased by nine to 10\% (Van Orsdel and Born 2008). Non-US titles in the humanities and social sciences increased even more (11\%), because publishers in these disciplines tend to price in native currencies, driving US prices up when those currencies are converted to dollars. The sciences, on the other hand, are dominated by large European publishers who price in US dollars, reducing the volatility of prices and keeping price increases in foreign scientific journals under $9 \%$. Van Orsdel and Born (2008) maintain that given the continuing slide of the dollar, increases in 2009 were expected to approach $10 \%$ overall. Van Orsdel and Born (2009) argue that the global economic recession has severely affected library budgets. Thus further library budgets cuts are expected at least until 2012 (Van Orsdel and Born 2009).

\subsection{Funding of university libraries in Africa}

Rosenberg (1997) conducted a review of the state of university libraries in Africa. The review highlighted the extremely poor, though widely varying, situations at different universities, both financially and otherwise. Thus preliminary findings from Rosenberg's review was discussed at the Standing Conference of African National and University Libraries in Eastern, Central and Southern Africa (SCANUL-ECS) in 1996 and the recurring problem of inadequate and decreasing funding for university libraries in general, was again discussed in detail. As a result, SCANUL-ECS decided to develop, formulate and finalise common guidelines, norms and standards, suitable for practical application in and by university libraries/librarians in the region for the following:

- Percentage of institutional income allocated to the library;

- Percentage of students' tuition fees allocated to the library;

- Recommended charges for income generation activities undertaken by the library; and

- Financial control and management of funds generated through library activities and services (Willemse 2002: 2). 
The percentage of institutional income allocated to the library, was the only criterion of concern for the present study. To formulate these norms and standards, John Willemse (2002) was commissioned to conduct a study to investigate the status quo of funding in university libraries in the region, as well as elsewhere on the continent.

The study noted that good libraries are essential for good universities and therefore need good funding. The study reviewed university funding at a global level before examining the state of funding in the region, and at the continental level. The major finding of the survey was that most of the libraries in the region were inadequately funded (Willemse 2002). The general recommendation of the study concerned the recognition of the indispensability of the library to the university, the need for autonomy of university libraries, regular collection of library statistics, and the need for approval by the Association of African Universities (AAU) of the terminology applicable in university libraries. The increasing proportion of the total university budget allocated to the library budget was pegged at about $6 \%$ to $7 \%$ of the total budget. The university should spend at least $6 \%$, if excellent service is required and $5 \%$ if normal generally acceptable levels are required (Willemse 2002: 35). Other recommendations included the adoption of standards as guidelines and performance measurements; income generation schemes to supplement the inadequate library funding and minimise the dependency on funding from the university. Other alternatives such as donor funding should also be explored (Willemse 2002).

2.5 Funding of university libraries in South Africa

Commenting on the history of the libraries of the University of Natal ${ }^{3}$, Buchanan (2008) notes that during the 1970s the South African economy showed signs of continuous increases in the rate of inflation which led to a devaluation of the rand. While these devaluations had a beneficial effect on the South African economy, they negatively affected academic libraries' purchasing power. Musiker and Musiker (1998), commenting on an earlier history of the University of the Witwatersrand Library, noted that the Library, together with other university libraries, entered a doubtful period in its financial history. Buchanan (2008) argued that the devaluation of the rand during the latter half of 1975, the rising costs of library materials and the imposition of a 15\% surcharge on imported books, which was introduced in 1977, all took their toll on South African academic libraries. According to Suttie (2005a) the only South African academic library which remained relatively unaffected by the unfavourable economic situation was the University of South Africa (UNISA) Library. On the positive side, Suttie (2005b: 284) maintains that during the 1970s higher costs "forced libraries to cooperate in order to cut down on unnecessary duplication". However, according to Buchanan (2008) such co-operation proved to have limited benefits for South African academic libraries. Also, the introduction of the South African Post Secondary Education (SAPSE) information system in 1980 had also changed the way in which the government calculated funding for universities. To add to the financial strain in 1984 the government had "introduced severe cuts in the subsidy to universities" (University of Natal 1989: I).

The deterioration in the rand/sterling and rand/dollar exchange rates from 1984 also had a detrimental effect on the library materials' budget since most academic libraries were largely dependent on imported books and journals (Buchanan 2008). Buchanan (2008) found that the libraries of the then University of Natal in order to balance their budgets were forced to cancel journals subscriptions and follow an extremely conservative policy when it came to ordering new subscriptions. Alarmingly, as early as 1958 unexpected increases in the prices of journal subscriptions resulted in over-expenditure on the journals budget of the University of Natal libraries which led to cancellations of subscriptions following a survey of academic staff (Buchanan 2008). In 1975 the University of Natal Librarians in their annual report noted that the overall increases in the cost of journal subscriptions had exceeded $50 \%$, negating the advantages of the considerably larger library allocation granted to the libraries (University of Natal 1975). Two years later, in 1977, when it was discovered that the ratio of journal to book expenditure was becoming unbalanced, a cancellation of journals subscriptions was carried out sporadically in an attempt to control expenditure (Buchanan 2008).

Gultig (2000), commenting on university finances in post-apartheid South Africa, argued that increases in inflation coupled with the declining value of the rand had resulted in dire consequences for library and other parts of university budgets. Commenting on the University of Natal in particular, Walker (2003) noted that at the beginning of the previous two decades, the resources offered by university libraries had been reasonable. However, since 1983 the situation had steadily deteriorated. Every year there had been calls for further cuts in subscriptions to journals. Fewer new book acquisitions had been made. In some faculties the cost of a substantially reduced set of journals exceeded the allocated budget for books and journals combined. It was thus a matter of great concern that the science facilities were the most effected, given that they are by far the most productive in research. Many of the journals cancelled were crucial to the work of leading researchers at these South African universities. Of more concern, was the fact that in more specialised fields these journals once cancelled, were not available elsewhere in the country. Walker (2003) argued that the situation

3. The University of Natal merged with the University of Durban-Westville in 2004 to form the University of KwaZulu-Natal. 
was so bad that university libraries' (multi-campus institutions) ability to meet the research objectives of the Department of Education's funding formula was seriously compromised.

Walker (2003) examined the budget allocations to libraries over a six year period: from 1997 to 2002, and revealed a funding pattern that had simply been continued on an historical bias without any regard for circumstances. As a consequence funding had fallen well behind the amount identified in the Government funding formula for library acquisitions. According to Walker (2003) a reasonable benchmark for determining the level of funding for books and journals was 1.75 times the government subsidy for books and journals. This figure was arrived at by noting that student fees and other income constituted 0.75 of the subsidy income, assuming that one should budget on the government subsidy plus a pro rata of fee income. Using the library budget of the then University of Natal, Walker showed that in 1997 the allocation for books and journals (R8.8I million) was $6 \%$ less than the government subsidy (R9.36 million).

Over the next six years the allocation steadily deteriorated. In 2002 the situation reached crisis level. Using the suggested benchmark figure the University of Natal libraries should have allocated about R4I.5 million to books and journals. Their actual allocation was only $42 \%$ of that. A further problem is that books and journals were bought from a common budget. As a result book purchases have suffered in order to maintain journal subscriptions. Buchanan (2008) also notes with concern that the book and journal allocation awarded to the then University of Natal was less than what the library had earned via the SAPSE formula.

Walker (2003) showed that the subsidy from the Department of Education had increased sharply in 2000, from approximately $4 \%$ of the subsidy allocation to the University to nearly $6 \%$ (which according to Willemse (2002) above, is the benchmark for academic library funding), indicating that the Department had taken cognisance of the large increases in the costs of library materials. This increase was not passed on by the University of Natal to its libraries. Walker (2003: 13) points out that $18 \%$ of the subsidy provided by the government for these libraries was being used "to fund other activities" and notably, no resources from non-subsidy income were allocated to these libraries, either.

Darch and Underwood (2005: 5) in their study which examined whether pre-compiled citation indexes of peer reviewed journals were an adequate control for research quality, particularly for library and information science, argued that local South African libraries would struggle to purchase international journals that contained the research of South African researchers which was funded in effect by the DoE and other funding bodies.

\section{Methodology}

The current study adopted a quantitative approach which involved the collection of data in the form of numbers and the use of statistical data analysis. A two-pronged method of data collection was adopted. The two methods used were the search for and review of the relevant literature and the use of survey research.

The previous studies relating to university library funding by Rosenberg (1997) and Willemse (2002) used the quantitative approach with a questionnaire being the major instrument for data collection. The present quantitative study used an online self-administered questionnaire (created using SurveyMonkey) directed to the heads of university libraries in South Africa as the key source of data. In the absence of a library head the periodicals or serials librarian completed the survey. The questionnaire of the Association of Learned and Professional Society Publishers (ALPSP) (Ware 2006) was adapted for the current study and then pre-tested before being used in the local context. The population of the study were the university libraries in South Africa. The 17 units of analysis were drawn from the Library and Information Association of South Africa (LIASA) Heads of Academic Libraries list. A total of 12 university libraries (representing 70.6\%) responded. The survey data was evaluated and analysed using SPSS. In terms of ethical considerations the online selfadministered questionnaire was anonymous and all responses were treated as confidential. Results were analysed in terms of frequency of responses and graphically displayed in the form of figures and tables.

\section{Results and discussion}

In an attempt to answer the research questions of the study the order of the discussion in this section follows that of the order of the key research questions of the study.

\subsection{Institutional budget allocation}

A question was asked to determine what percentage of the institutional budget was allocated to the university libraries. Table I shows the institutional percentage allocation to the university libraries.

Table I reveals that only two (16.7\%) university libraries received more than the benchmark figure of $6 \%$ from their institutions. A further two (16.7\%) libraries received $6 \%$ or close to $6 \%(5.59 \%)$. However, some university libraries were less fortunate and only received an allocation of approximately $3 \%$. More alarming however, was the fact that four (33.3\%) university libraries were not sure what their institutional budget allocation was. One would expect the libraries to know what the allocation was in order to lobby for more funding or at least for the benchmark figure of $6 \%$ required 
for an efficient library service. According to Willemse (2002) the increasing proportion of the university budget allocated to the library should be about $6 \%$ to $7 \%$ of the total budget. This would suggest that a majority (80\%) of South African university libraries were underfunded by their parent organisations and held back from offering an excellent service. The results of the present study concluded that South African university libraries like their African counterparts experienced difficulties with their library budgets as noted by Rosenberg (1997) in her review of university libraries in Africa.

Table I Institutional budget allocation $(\mathrm{N}=12)$

\begin{tabular}{|l|l|l|}
\hline \multirow{2}{*}{ Institutional budget allocation } & Responses \\
\cline { 2 - 3 } & Frequency & Percent \\
\hline $20 \%$ & $\mathrm{I}$ & $8.3 \%$ \\
\hline $\mathrm{I} \%$ & $\mathrm{I}$ & $8.3 \%$ \\
\hline $6 \%$ & $\mathrm{I}$ & $8.3 \%$ \\
\hline $5.59 \%$ & $\mathrm{I}$ & $8.3 \%$ \\
\hline $4.5 \%$ & $\mathrm{I}$ & $8.3 \%$ \\
\hline $3.86 \%$ & $\mathrm{I}$ & $8.3 \%$ \\
\hline $2.8 \%$ & $\mathrm{I}$ & $8.3 \%$ \\
\hline $2.7 \%$ & $\mathrm{I}$ & $8.3 \%$ \\
\hline Unsure & 4 & $33.3 \%$ \\
\hline Total & 12 & $100 \%$ \\
\hline
\end{tabular}

\section{I.I Increase in institutional budget allocation}

A question was asked to determine whether the institutional allocation made to the university libraries had increased over the last three years. Only five (4I.7\%) of the libraries stated that they had received an increase in their institutional budget allocation. Almost as many university libraries, three or $25 \%$, stated that their institutional budget allocation to their library had not increased. Coupled with this, four (33.3\%) libraries, did not respond to the question. This nonresponse could have been as a result of not knowing what their institutional budget allocation was. These results are significant since an inflationary increase in the price of subscriptions was considered an important factor in determining cancellation (Martell 2003). It can be inferred that the four (33.3\%) libraries who were unsure of their budget also did not know whether they had received an increase in their institutional allocation for the last three years. Given that the price of journal titles is an important factor in determining cancellation one would assume that university libraries know what their institutional budget allocations are, as well as what the percentage increase to the budget allocation is so that they can make informed decisions when cancelling titles. As noted, Gultig (2000) identified dire consequences for library and other parts of university budgets as a result of inflation coupled with the declining value of the rand. Also, as noted earlier by Edwards and Shulenburger (2003) inflationary increases in the price of subscriptions were considered an important factor in cancelling titles, yet only five (4I.7\%) university libraries had received an increase in their institutional budget allocation.

\section{I.2 Reasons for no increase in institutional budget allocation}

A follow-up to the previous question required the respondents to explain why their library had not received an increase in their budget allocation from the institution. Table 2 shows the three reasons given by the three libraries concerned as to why the libraries had not received an increase in their budget allocation.

Table 2 Reasons for no increase in institutional budget allocation $(\mathrm{N}=3)$

\begin{tabular}{|l|}
\hline Reasons for no increase in budget \\
\hline Decreased due to lack of appreciation of factors impacting on library expenditure \\
\hline The merger has complicated matters, we did not have a proper formula in place and there was a general decrease in subsidy overall \\
\hline $\begin{array}{l}\text { University is working with a deficit budget; i.e. total university expenditure is more than income. It has therefore been impossible to raise } \\
\text { the library materials budget to the hoped for } 6 \% \text { of the total budget }\end{array}$
\end{tabular}

Each of these three university libraries provided one reason. These explanations of the lack of increase in the institutional budget for these three (25\%) libraries reveal the context within which South African university libraries operate. It would 
appear from Table 2 that the reasons provided were that there is a lack of appreciation for the role of the university library in South Africa. University library budgets have not increased and this places an added financial burden on the libraries to cope with the inflationary price of titles.

\subsection{Separate budgets for print and electronic resources}

A question was asked to determine whether the university libraries had separate budgets for their print and electronic resources. More than half (seven or 58.3\%) of the libraries had a separate budget for print and electronic resources, while five $(41.7 \%)$ did not.

\subsection{Reduced expenditure to provide electronic resources}

A question was asked to determine if the university libraries had reduced expenditure in any areas in order to provide electronic resources. Of the university libraries, five (4I.7\%) had reduced expenditure in other areas in order to provide electronic resources, while half the university libraries (six or $50 \%$ ) had not.

\subsubsection{Areas in which expenditure was reduced}

A follow-up question to the previous question required the five (41.7\%) university libraries that had reduced expenditure to provide electronic resources to indicate in which areas they had reduced expenditure.

Only two (40\%) libraries were aware of the area in which they had reduced expenditure to provide electronic resources. These two (40\%) libraries had reduced expenditure on monographs to provide electronic resources. However, three $(60 \%)$ of the libraries did not respond to the question and one could infer that they were not aware of which areas were being subjected to reduced expenditure in order to provide electronic resources. Walker (2003) noted that a problem with university library budgets was that books and journals were bought from a common budget. As a result book purchases had suffered in order to maintain periodical subscriptions. Therefore, the five (4I.7\%) libraries that did not have separate print and electronic budgets could be compromising the purchase of monographs in their libraries as they used one budget to maintain their electronic periodical subscriptions and purchase monographs.

This observation is in keeping with the literature where Edwards and Shulenburger (2003) found that to increase the budget for journal subscriptions, the average library in the US cut back severely on monograph purchases by $17 \%$, as well as on other services. Martell (2003) argues that cancelling print in favour of electronic journals has resulted in a paradigm shift since academic libraries have adopted a paradigm that reflected the fiscal realities, namely, the access paradigm (Martell 2003). It could be argued that most South Africa university librarians are undergoing this paradigm shift that Martell (2003) refers to as they move from print to electronic journals.

4.3 Materials budget allocation to periodicals

A question was asked to determine what percentage of the university libraries' materials budget was allocated to periodical or serial subscriptions. The results are shown in Table 3.

Table 3 Materials budget allocation to periodicals $(\mathrm{N}=12)$

\begin{tabular}{|l|l|l|}
\hline \multirow{2}{*}{ Allocation for periodicals } & Responses & Percent \\
\cline { 2 - 3 } & Frequency & $8.3 \%$ \\
\hline $92 \%$ & $\mathrm{I}$ & $8.3 \%$ \\
\hline $89 \%$ & $\mathrm{I}$ & $8.3 \%$ \\
\hline $85 \%$ & $\mathrm{I}$ & $8.3 \%$ \\
\hline $83 \%$ & $\mathrm{I}$ & $16.7 \%$ \\
\hline $75 \%$ & 2 & $8.3 \%$ \\
\hline $70 \%$ & $\mathrm{I}$ & $8.3 \%$ \\
\hline $69 \%$ & $\mathrm{I}$ & $8.3 \%$ \\
\hline $60 \%$ & $\mathrm{I}$ & $8.3 \%$ \\
\hline $40 \%$ & $\mathrm{I}$ & $16.7 \%$ \\
\hline Unsure & 2 & $100 \%$ \\
\hline Total & 12 & \\
\hline
\end{tabular}

Table 3 reveals that of the 12 university libraries, one (8.3\%) had allocated more than $90 \%$ of their materials budget to periodicals. This was followed by three (25\%) libraries that each had a periodical budget allocation within the $80-89 \%$ range. A further two (16.7\%) libraries had a periodicals budget allocation which was in the $70-79 \%$ range, while two (16.7\%) more libraries periodicals budget allocation was in the $60-69 \%$ range. Only one (8.3\%) library had received less 
than a $50 \%$ periodical budget allocation with a $40 \%$ allocation to periodicals. More alarmingly, two (I6.7\%) of the university libraries were not sure what percentage of their materials budget had been allocated to periodicals.

\subsection{Materials budget allocation to monographs}

A question was asked to determine what percentage of the university libraries' materials budget was allocated to monograph or book purchases. Table 4 shows the percentage the university libraries allocated to monograph or book purchases from the materials budget.

Table 4 Materials budget allocation for monographs $(\mathrm{N}=12)$

\begin{tabular}{|c|c|c|}
\hline \multirow[t]{2}{*}{ Allocation for monographs } & \multicolumn{2}{|l|}{ Responses } \\
\hline & Frequency & Percent \\
\hline $60 \%$ & I & $8.3 \%$ \\
\hline $40 \%$ & I & $8.3 \%$ \\
\hline $31 \%$ & 1 & $8.3 \%$ \\
\hline $30 \%$ & 1 & $8.3 \%$ \\
\hline $25 \%$ & 1 & $8.3 \%$ \\
\hline $17 \%$ & 1 & $8.3 \%$ \\
\hline $15 \%$ & 1 & $8.3 \%$ \\
\hline $11 \%$ & 1 & $8.3 \%$ \\
\hline $8 \%$ & 1 & $8.3 \%$ \\
\hline Unsure & 2 & $16.7 \%$ \\
\hline No response & 1 & $8.3 \%$ \\
\hline Total & 12 & $100 \%$ \\
\hline
\end{tabular}

When compared with Table 3, Table 4 shows that only one (8.3\%) university library had received more than a $50 \%$ materials budget allocation for monographs. Again, two (16.7\%) were unsure of their percentage budget allocation for monographs and one (8.3\%) library did not respond. One can infer that these libraries would not be able to ascertain if the ratio between their periodical and monograph purchases was balanced. In terms of the materials budget allocated to periodicals the results in Table 3 show that four (33.3\%) libraries had a periodicals budget allocation within the range of 83 to $92 \%$. This means that these libraries were only allocating between 8 to $17 \%$ of their materials budget to monograph purchases. In direct contrast to this, Table 4 shows that only one (8.3\%) library had a monograph budget allocation of more than $60 \%$. Both Table 3 and 4 are a clear indication that university libraries in South Africa allocate a greater percentage of their materials budget to periodicals than to monographs. This allocation would result in fewer monograph purchases.

In Figure I Gooden, Owen, Simon and Singlehurst (2002) show that the periodicals budget (26\%) for US academic libraries at the time was more than double that of the monograph budget ( I \%) allocation. The Association of Research Libraries (2008) in Figure 2 shows that the increases in periodical subscriptions had impacted on monograph purchases to the extent that they had shown a negative growth of $9 \%$ from 1986 to 2004 in US research libraries.

4.5 Number of subscriptions and institutional allocation

In the study the number of journal subscriptions was cross tabulated with the percentage institutional budget allocation of the university library to see if the libraries that received larger institutional budget allocations had more titles.

Table 5 shows that the university library with the most subscriptions, 5 I 349, had an institutional budget allocation for the library of $6 \%$. Two of the libraries that had 46780 and 40000 titles, each, were unsure of their institutional budget allocation. All of the libraries that had less than 10000 titles had an institutional budget allocation of less than the benchmark figure for the library of $6 \%$ or were unsure of their budget allocation. Table 5 shows that the university library with the most subscriptions, 5 I 349, had an institutional budget allocation of $6 \%$. This would suggest that libraries with a $6 \%$ or more institutional budget allocation had greater buying power and could subscribe to more journals. However, an exception to this is the library that had the largest periodical budget allocation of $20 \%$ had only 2000 subscriptions. A possible explanation is that the university library was not sure of their actual institutional budget allocation, or the figure they provided was calculated incorrectly. This explanation could also be applied to the library that had an II\% periodicals' budget allocation but only had 30000 subscriptions.

SA JnI Libs \& Info Sci 20I I, 77(I) 
Table 5 Number of subscriptions and institutional allocation $(\mathrm{N}=12)$

\begin{tabular}{|c|c|c|c|c|c|c|c|c|c|c|}
\hline \multirow[b]{2}{*}{ Number of subscriptions } & \multicolumn{9}{|c|}{ Percentage of budget allocated to library } & \multirow[b]{2}{*}{ Total } \\
\hline & $2.7 \%$ & $2.8 \%$ & $3.86 \%$ & $4.5 \%$ & $5.59 \%$ & $6 \%$ & $11 \%$ & $20 \%$ & Unsure & \\
\hline 51349 & 0 & 0 & 0 & 0 & 0 & 1 & 0 & 0 & 0 & 1 \\
\hline 46780 & 0 & 0 & 0 & 0 & 0 & 0 & 0 & 0 & 1 & 1 \\
\hline 40000 & 0 & 0 & 0 & 0 & 0 & 0 & 0 & 0 & I & 1 \\
\hline 30000 & 0 & 0 & 0 & 0 & 0 & 0 & 1 & 0 & 0 & $I$ \\
\hline 27000 & 0 & 0 & 0 & I & 0 & 0 & 0 & 0 & 0 & $I$ \\
\hline 23000 & 0 & 0 & 0 & 0 & 0 & 0 & 0 & 0 & $I$ & $I$ \\
\hline 20000 & 1 & 0 & 0 & 0 & 0 & 0 & 0 & 0 & 0 & $I$ \\
\hline 6500 & 0 & 1 & 0 & 0 & 0 & 0 & 0 & 0 & 0 & $I$ \\
\hline 2769 & 0 & 0 & 0 & 0 & 1 & 0 & 0 & 0 & 0 & $I$ \\
\hline 2000 & 0 & 0 & 0 & 0 & 0 & 0 & 0 & 1 & 0 & $I$ \\
\hline 1300 & 0 & 0 & 1 & 0 & 0 & 0 & 0 & 0 & 0 & $I$ \\
\hline 758 & 0 & 0 & 0 & 0 & 0 & 0 & 0 & 0 & 1 & 1 \\
\hline Total & 1 & 1 & 1 & I & 1 & 1 & $I$ & $I$ & 4 & 12 \\
\hline
\end{tabular}

4.6 Reasons for journal cancellations

A multiple response question required the respondents to explain why they had cancelled journals. Reasons for journal cancellations are reflected in Table 6.

Table 6 Reasons for journal cancellations in the past five years $(\mathrm{N}=12)$

\begin{tabular}{|l|l|l|}
\hline \multirow{2}{*}{ Reasons for journal cancellations } & \multicolumn{2}{l|}{ Responses } \\
\cline { 2 - 3 } & Yes & Percent \\
\hline Cuts in periodicals budget & 5 & $41.7 \%$ \\
\hline Price increase & 5 & $41.7 \%$ \\
\hline High price & 4 & $33.3 \%$ \\
\hline Duplication of subscriptions resulting from an institutional merger & 2 & $16.7 \%$ \\
\hline Print journals cancelled where electronic version is accessible in a database & 2 & $16.7 \%$ \\
\hline Changes in curriculum & 1 & $8.3 \%$ \\
\hline Not meeting teaching and research needs & 1 & $8.3 \%$ \\
\hline Subject area no longer taught & 1 & $8.3 \%$ \\
\hline Replacing print subscriptions with online & 1 & $8.3 \%$ \\
\hline
\end{tabular}

The main reasons why university libraries have been cancelling journal titles include cuts in periodical budgets (five or $41.7 \%$ ), price increases in journal titles (five or $41.7 \%$ ) and the high price of journals (four or 33.3\%). Institutional mergers of academic institutions had resulted in duplication of subscriptions at two ( $16.7 \%$ ) of the university libraries. This duplication provided a reason to rationalise and cancel titles at these two libraries. Print journals were cancelled when an electronic version became available by two (16.7\%) of the libraries. Reasons for cancelling as a result of curricula concerns were provided by three (25\%). Each of these libraries cancelled because of changes in the curriculum (one or $8.3 \%$ ), journal titles that were not relevant because they did not meet the institutions teaching or research needs (one or $8.3 \%$ ), and titles for subject areas that were no longer taught (one or $8.3 \%$ ). As a result of budget constraints a majority $(80 \%)$ of the universities' libraries were experiencing difficulties in maintaining subscriptions to journals since the budget was not adequate for the acquisition needs of the libraries. Instead of providing a reason for cancelling, one (8.3\%) of the university libraries pointed out that they could not cancel titles that were tied-up in a 'big deal' as noted by Edwards and Shulenburger (2003).

4.7 Subscribing to new journals

A question was asked to determine if the university libraries were still subscribing to new journals. All 12 university libraries were still subscribing to new journal titles. This finding is significant given that all 12 were cancelling titles as well. 


\subsection{Restrictions on new journal subscriptions}

A follow-up question to the previous question required the respondents who were subscribing to new journals to indicate any restrictions they were imposing on new journal subscriptions. Table 7 reveals the restrictions university libraries were imposing on new journal subscriptions. Respondents could provide more than one reason.

Table 7 New journal subscription restrictions $(\mathrm{N}=12)$

\begin{tabular}{|c|c|c|}
\hline \multirow[t]{2}{*}{ New journal subscription restrictions } & \multicolumn{2}{|l|}{ Responses } \\
\hline & Frequency & Percent \\
\hline New journals are only considered if journals of equal price are cancelled & 5 & $41.7 \%$ \\
\hline Department must make funding available from their book fund & 2 & $16.7 \%$ \\
\hline $\begin{array}{l}\text { Depends on cost of periodical e.g. cheaper titles (such as South African titles) can } \\
\text { be purchased without having to cancel anything. The more expensive titles and/or }\end{array}$ & 2 & $16.7 \%$ \\
\hline $\begin{array}{l}\text { Will not subscribe to new print if already available electronically in databases } \\
\text { subscribed to }\end{array}$ & 2 & $16.7 \%$ \\
\hline Electronic subscriptions favoured over print & I & $8.3 \%$ \\
\hline There should be a reasonable demand for a title & I & $8.3 \%$ \\
\hline New title should be relevant and complement the collection & I & $8.3 \%$ \\
\hline No response & I & $8.3 \%$ \\
\hline
\end{tabular}

According to five (4I.7\%) university libraries, new journals could only be subscribed to if journals of equal price were cancelled. This finding suggests that budgetary constraints are the main restriction on subscribing to new journal titles. At two (16.7\%) universities, new journals could only be subscribed to if academic departments made the funding available for these new titles. An interesting restriction imposed by two (16.7\%) university libraries depended on the cost of the title where it was argued that South African titles were cheaper so could be subscribed to. However, more expensive titles could only be subscribed to if something else was cancelled. New print titles were not subscribed to by two (16.7\%) of the libraries if they were available in an electronic database. A reasonable demand for the new journal was mentioned by one (8.3\%) library. Relevance of the new journal was only a consideration for one (8.3\%) of the libraries. One could argue that the periodical collections of South African university libraries are not increasing as South African librarians have to annually engage in routine journal cancellations due to budget constraints.

\section{Conclusion and recommendations}

Although university libraries in South Africa are considered important for their research function they are underfunded by their parent institutions and are therefore faced with budget constraints. As a result of these budget constraints local university libraries experience difficulties in maintaining their subscriptions to journals. Unlike their counterparts in other countries, South African university libraries are further affected by the exchange rate and the generally weakening rand. South Africa university libraries therefore have to pay higher prices for journal subscriptions than those expected or budgeted for. Consequently, most university libraries in South Africa are insufficiently resourced to meet the research needs of their universities.

Most university libraries in South Africa are underfunded to the extent that they do not receive more than $6 \%$ of the institutional budget which is the benchmark for a generally acceptable level of funding. Alarmingly, some university librarians are not aware of what percentage of their total institutional budget is allocated to the library. Given that most university libraries in South Africa are faced with budget constraints, librarians who are unaware of their percentage allocation cannot lobby for more funding or deal adequately with the annual inflationary price increase of journals and the added burden of the exchange rate. Also, such libraries cannot make informed decisions when cancelling journal titles.

University library budgets in South Africa have decreased due to inflation and institutional demands even though some libraries still receive annual budget increases. University libraries which received an institutional allocation of $6 \%$ or more have greater buying power and can subscribe to more journals. As a result these libraries are better able to support the research needs of their institutions in addition to providing a more efficient and effective service to their users.

SA Jnl Libs \& Info Sci 20I I, 77(I) 
Although most university libraries in South Africa have a separate budget for print and electronic resources, those that do not are compromising the purchasing of monographs in their libraries as they use one budget to maintain their increasingly costly journal subscriptions and purchase monographs. As mentioned earlier, university libraries in South Africa, like their counterparts in other countries, allocate a greater percentage of their materials budget to periodicals than to monographs. This allocation results in fewer monograph purchases. Therefore, one could argue that the collections of most university libraries in South Africa are becoming skewed towards maintaining journal subscriptions at the expense of a well-resourced monograph collection.

To mitigate some of these difficulties, university librarians should make a concerted effort to ensure that they are adequately funded by their parent organisations. Based on the above conclusions the following recommendations were made by the study:

- University libraries have to know what percentage of their total institutional budget is allocated to the library. Regardless of how the library budget is made up, that is the percentage allocated from student fees, government subsidy and outside donations or funding, librarians must know the actual percentage allocated to the library. Without this knowledge librarians are operating in a knowledge vacuum with regard to these critical issues and therefore cannot make informed decisions on journal cancellations and the operation of the library.

- Since university libraries are crucial in terms of the research function of a university, university librarians must lobby their parent institutions to provide them with an institutional allocation of $6 \%$ or more to ensure that they can maintain an effective and efficient library service.

- University librarians should lobby and motivate not only for a minimum of a $6 \%$ institutional budget allocation, but should also ensure that the allocation made to the library takes inflation into account.

- University libraries should have separate budgets for journal subscriptions and monograph purchases. In this way the purchasing of monographs is not compromised by a joint budget that is used only to maintain journal subscriptions.

- South African university libraries must know what percentage of their university libraries' journal content is freely available. University libraries must put in place plans to take advantage of the freely available content that overlaps with their collection. At the consortium level university libraries should be aware of what content is available in other university libraries to prevent unnecessary duplication.

- An important and vital function for university libraries in South Africa is to facilitate the access to research produced by local scholars. University libraries need to take advantage of the funding opportunities provided by organisations such as the NRF to establish such institutional repositories. Also, university libraries must ensure that their staff are adequately trained and have the necessary knowledge and skills to administer and maintain their institutions repository.

- University libraries in South Africa need to embrace open access initiatives by facilitating access to open access content for their users. South African university librarians need to start considering journals in their preprint form and particularly in their postprint, as acceptable substitutes for the journal. University librarians should encourage local scholars to make use of open access initiatives by alerting scholars of such initiatives.

\section{References}

Association of Research Libraries. 2008. Serial expenditures in ARL libraries. [Online]. http://www.arl.org/sc/marketplace/ serials.shtml. (Accessed 16 May 2008).

Buchanan, N. 2008. A history of the University of Natal Libraries, 1910-2003. PhD. thesis. Pietermaritzburg: University of KwaZulu-Natal.

Darch, C. \& Underwood, P. 2005. Are pre-compiled citation indexes of peer-reviewed journals an adequate control for research quality?: a case study of library and information science. South African Journal of Libraries and Information Science, $7 I(I): I-10$.

Edwards, R. \& Shulenburger, D. 2003. The high cost of scholarly journals (and what to do about it). Change, 35(6): $10-19$.

Gooden, P., Owen, M., Simon, S. \& Singlehurst, L. 2002. Scientific publishing: knowledge is power. Media industry overview report. New York: Stanley Morgan.

Gultig, J. 2000. Globalisation and the idea of the university in the post-apartheid South Africa. Journal of Education, 25: 63-89.

Hoon, P. 2003. Who woke the sleeping giant?: libraries, copyrights, and the digital age. Change, Nov.: 28-33.

Martell, C. 2003. The role of librarians in the twenty-first century. Encyclopedia of library and information science. $2^{\text {nd }}$ ed. New York: Marcel Dekker. vol. 8. pp. 2524-2536.

Musiker, R. \& Musiker, N. 1998. Wits library: a centenary history. Johannesburg: Scarecrow.

Rosenberg, D. 1997. University libraries in Africa: a review of their current state and future potential. London: International African Institute.

Suttie, M. 2005a. The formative years of the University of South Africa Library, 1946 to 1976. Mousaion, 23(I): 97-I I8.

Suttie, M. 2005b. The University of South Africa Library: from the Soweto rebellion to the beginning of the end of apartheid. Mousaion, 24(2): 283-312.

University Grants Committee on Libraries. 1967. Report of the Committee on Libraries: the Parry Report. London: HMSO.

University of Natal. 1975. Librarian's 14th annual report. Pietermaritzburg: University of Natal.

University of Natal. 1989. The role in society of the University of Natal, 1989 onwards. Durban: University of Natal. 
Van Orsdel, L. \& Born, K. 2007. Periodicals price survey 2007: serial wars. Library Journal, I32(7): 43-48. [Online] http:// www.libraryjournal.com/article/CA6431958.html (Accessed I4 April 2008).

Van Orsdel, L. \& Born, K. 2008. Periodicals price survey 2008: embracing openness. Library Journal, I33(7): 53-58. [Online] http://www.libraryjournal.com/article/CA6547086.htmll (Accessed 20 February 2009).

Van Orsdel, L. \& Born, K. 2009. Reality bites: periodicals price survey 2009. Library Journal, I34(7): 36-40. [Online] http:// www.libraryjournal.com/article/CA665 I248.html (Accessed 07 August 2009).

Walker, D. 2003. Funding policies in the university libraries. Report presented to the University Planning and Resources Committee. Durban: University of Natal, Research Office.

Ware, M. 2006. ALPSP survey of librarians on factors in journal cancellation. West Sussex: ALPSP.

Willemse, J. 2002. Library funding; adequate financial support for African university funding. Oxford: INASP. 